\title{
Pulmonary Lesions in Female Harlan Sprague-Dawley Rats Following Two-Year Oral Treatment with Dioxin-Like Compounds
}

\author{
Nigel J. Walker ${ }^{1}$, Katsuhiko Yoshizawa ${ }^{2,3}$, Rodney A. Miller ${ }^{4}$, Amy E. Brix ${ }^{4}$, Donald M. \\ Sells $^{5}$, Micheal P. Jokinen ${ }^{6}$, Michael E. Wyde ${ }^{1}$, Michael Easterling ${ }^{7}$, and Abraham Nyska ${ }^{1,8}$ \\ 1 National Toxicology Program, National Institute of Environmental Health Sciences, Research Triangle \\ Park, North Carolina, USA \\ 2Toxicologic Pathology, Drug Safety Research Laboratories, Astellas Pharma Inc., Yodogawa, Osaka, Japan \\ 3Pathology II, Kansai Medical University, Moriguch, Osaka, Japan \\ 4Experimental Pathology Laboratories (EPL), Inc., Research Triangle Park, North Carolina, USA \\ 5 Battelle, Columbus Laboratories, Columbus, Ohio, USA \\ 6Pathology Associates, Inc., A Charles River Company, Durham, North Carolina, USA \\ 7Constella Group, Research Triangle Park, North Carolina, USA \\ 8Toxicologic Pathologist, Haharuv 18, 36576, Timrat, Israel
}

\begin{abstract}
Dioxin and dioxin-related compounds have been associated with high incidences of pulmonary dysfunctions and/or cancers in humans. To evaluate the relative potencies of effects of these compounds, the National Toxicology Program completed a series of two-year bioassays which were conducted using female Harlan Sprague-Dawley rats. The rats were treated orally for up to 2 years with 2,3,7,8-tetrachlorodibenzo- $p$-dioxin (TCDD), 3,3',4,4',5-pentachlorobiphenyl (PCB126), 2,3,4,7,8-pentachlorodibenzofuran (PeCDF), and a ternary mixture of TCDD, PCB126 and PeCDF. In addition to treatment-related effects reported in other organs, a variety of pulmonary lesions were observed that were related to exposure. Pulmonary CYP1A1-associated 7-ethoxyresorufin-Odeethylase (EROD) activity was increased in all dosed groups. The most common non-neoplastic lesions, which occurred in all studies, were bronchiolar metaplasia and squamous metaplasia of the alveolar epithelium. Cystic keratinizing epithelioma was the most commonly observed neoplasm which occurred in all studies. A low incidence of squamous cell carcinoma was associated only with PCB126 treatment. Potential mechanisms leading to altered differentiation and/or proliferation of bronchiolar and alveolar epithelia may be through CYP1A1 induction or disruption of retinoid metabolism.
\end{abstract}

\section{Keywords}

lung; cystic keratinizing epithelioma; bronchiolar metaplasia; carcinogenesis; mixtures; TEFs

Address correspondence to Nigel Walker, National Institute of Environmental Health Sciences, 111 Alexander Drive PO Box 12233 , MD EC-34, Research Triangle Park, NC 27709, USA; e-mail: walker3@niehs.nih.gov. 


\section{Introduction}

2,3,7,8-tetrachlorodibenzo- $p$-dioxin (TCDD) is commonly referred to as dioxin and certain polychlorinated dibenzodioxins (PCDDs), polychlorinated dibenzofurans (PCDFs), and coplanar polychlorinated biphenyls (PCBs) have the ability to bind to the aryl hydrocarbon receptor (AhR) and exhibit biologic actions similar to those of TCDD; they are commonly referred to as dioxin-like compounds (DLCs). They may induce developmental, endocrine, and immunological toxicity and multi-organ carcinogenicity in animals and/or humans (ATSDR, 1998, 2000; Bertazzi et al., 2001; Kociba et al., 1978; Steenland et al., 2001). In particular, TCDD has been listed as a Group 1 carcinogen (carcinogenic to humans, non-genotoxic carcinogen) by the International Agency for Research on Cancer in 1997 (IARC Carcinogen classification on web: http://www.iarc.fr/ENG/Databases/index.php), while PCBs have been listed as a Group 2A carcinogen (probably carcinogenic to humans). Pulmonary cancer risks were found to be increased in individuals exposed to TCDD during the 20-year period following the "Seveso Accident" at a chemical plant in Seveso, Italy in 1976 (Bertazzi et al., 2001; Pesatori et al., 2003). Also, increased pulmonary diseases and cancers were seen in several cohorts exposed either accidentally or occupationally to dioxins (Zober et al., 1994, 1997,1998; Fingerhut et al., 1991, Reggiani, 1980). Increased risk of pulmonary diseases and cancers were also seen in individuals from the "Yusho Accident" in Japan and/or "Yu-Cheng Accident" in Taiwan, that were exposed to rice oil contaminated by PCBs (ATSDR, 2000; Kikuchi, 1984; Nakanishi and Shigematsu, 1991).

The National Toxicology Program (NTP) recently conducted 2-year bioassays in female rats to evaluate the chronic pathology and carcinogenicity induced by dioxin, DLCs, structurallyrelated PCBs, and mixtures of these compounds, including TCDD; 3,3',4,4',5-

pentachlorobiphenyl (PCB126); 2,3,4,7,8-pentachloro-dibenzifyran (PeCDF); and the Toxic Equivalency Factor (TEF) ternary mixture of TCDD, PCB126, and PeCDF (National Toxicology Program,2004a,b,c,d). In these studies, there was an increase in the incidence of neoplasms and non-neoplastic lesions in several organs notably the liver, lung and oral mucosa (National Toxicology Program, 2004a,b,c,d; Walker et al., 2005, 2006; Hailey et al., 2005; Jokinen et al., 2003; Nyska et al., 2004, 2005; Tani et al., 2004; Yoshizawa et al., 2005a, b). This present article, one of a series of works highlighting specific findings from NTP dioxinTEF-evaluation studies, focuses on a comparative analysis of pulmonary effects across these studies.

\section{Materials and Methods}

These animal studies were done in accordance with the Good Laboratory Practices (Food and Drug Administration 2002) at Battelle Columbus Operations in Columbus, Ohio. For these studies female Sprague-Dawley rats were obtained from Harlan Laboratories, Indianapolis, Indiana. They were approximately 6 weeks of age upon receipt, underwent health screening during a quarantine period of about 2 weeks, and released for study when about 8 weeks old. The animals were randomly assigned to their respective experimental groups and permanently identified by tail tattoo. Rats were housed 5 per cage in solid-bottom polycarbonate cages (Lab Products, Inc. Maywood, NJ) suspended on stainless steel racks. Filtered room air was supplied at the rate of at least 10 room-changes per hour. The rats were maintained at 69-75 degrees $\mathrm{F}$, in a relative humidity of $35-65 \%$, and with a light/dark cycle of 12 hours. Food (irradiated NTP-2000 pellets from Zeigler Bros. Inc., Gardners, PA) and water were provided ad libitum. All rats were observed twice a day for morbidity and once a day for formal clinical signs of toxicity. Moribund animals were sacrificed and necropsied. Health monitoring via sentinel animals showed no evidence of any significant rodent pathogens. Animal husbandry was done in accordance with the National Institutes of Health guidelines (Institute of Laboratory Animal Resources, 1996). 
Groups of female Harlan Sprague-Dawley rats were treated by gavage with several doses of TCDD, PCB126, PeCDF, and a ternary mixture of TCDD, PCB126, and PeCDF (TEF Mixture) (Table 1). The rats were dosed once daily for 5 days per week for up to 2 years. In addition, the studies included a "stop-exposure" group whereby animals were exposed for 30 weeks at the highest dose for each test article, followed by vehicle control until the end of the study. Doses used were based on Toxic Equivalency Factor values selected by the World Health Organization (Van den Berg et al., 1998) (Table 1).

Dose formulations of TCDD (IIT Research Institute, Chicago, IL), PCB126 (AccuStandard, Inc. New Haven, CT), and PeCDF (Cambridge Isotope Laboratories, Cambridge, MA) were prepared by formulating the test articles in a corn-oil vehicle containing $1 \%$ USP-grade acetone. Purities of TCDD, PCB126, and PeCDF were determined to be approximately 98\%, 99.51\%, and $97 \%$ respectively. Chemical purity was stable over the course of the studies. Dose formulations were prepared fresh on a monthly basis and the mixture was stable for that period of time.

Moribund rats and all scheduled sacrifice rats were euthanized by using carbon dioxide. All study rats were necropsied according to standard procedures and complete tissue sets, including all gross lesions and masses, were fixed in $10 \%$ neutral-buffered formalin. All collected tissues were trimmed after fixation, processed and embedded in paraffin. The tissues were then sectioned at approximately 5 microns thickness, stained with hematoxylin and eosin and examined via light microscopy. The pathology findings underwent the comprehensive NTP peer review and Pathology Working Group review (Boorman, 2002).

To evaluate the expression of known dioxin-responsive genes, pulmonary CYP1A1-associated 7-ethoxyresorufin-O-deethylase (EROD) activity was analyzed in all dosed groups at 14, 31 and 53 weeks for all studies. EROD data, which have typically skewed distributions, were analyzed using the nonparametric multiple comparison methods of Shirley (1977), as modified by Williams (1986) and Dunn (1964).

Dose-response modeling, calculation of the relative potency and statistically based hypothesis testing of same shape dose-response curves, dose additivity for the mixture and suitability of the World Health Organization (WHO) TEFs was carried as described by Toshiba et al. (2004) and Walker et al. (2005), respectively. The dose-specific incidences of non neoplastic lesions were survival adjusted using the poly- 3 adjustment and modeled using a Hill function. Parameters were estimated using maximum likelihood techniques assuming a binomial distribution for the tumor counts. Chi-square-based likelihood ratio tests were used to evaluate all hypotheses. Relative potency factors (RPFs) were calculated and presented under the assumption of the same "Shape" model whereby data from the 4 studies were modeled under conditions where the $\mathrm{B}_{0}, \mathrm{~B}_{\max }$ and Hill parameters were shared across the studies. Under these conditions the dose responses were parallel across the dose range, so the RPF is calculated as the ratio of the respective test article $\mathrm{ED}_{50} \mathrm{~s}$ to that of TCDD.

Initially each dataset was modeled with parameters describing the dose response unrestricted, allowing an independent optimal fit for each chemical or mixture. This model was then compared to a model (Same Shape) in which the only parameter that was unique to each compound was the half maximal dose $\left(\mathrm{ED}_{50}\right)$. By comparing the error associated with the two model fits, we tested the null hypothesis that a common shape model was as good a fit as the optimal independent fit. The second hypothesis to be tested was whether the increased incidence for the mixture for each effect was consistent with a potency adjusted dose additive combination of the individual effects of TCDD, PCB126 and PeCDF. This was achieved by comparison of the additive model to the Same Shape model, for each respective lesion. Finally, we tested the hypothesis that the current WHO TEFs for PCB126 (0.1) and PeCDF (0.5) (Van 
den Berg et al., 1998) could be used rather than the optimal RPFs. For this test we compared the fits for the WHO model and the additive model.

\section{Results}

All individual animal data for these studies can be found on the NTP web site (http://ntp.niehs.nih.gov/go/datasearch) and are summarized in individual technical reports on the evaluation of their carcinogenicity (NTP 2004a, b, c, d). Treatment related lesions of the lung were commonly observed in this series of studies and are presented by study in Table 2 .

Bronchiolar metaplasia of the alveolar epithelium (alveolar epithelium, metaplasia, bronchiolar; AEMB) was the most common lesion associated with this series of compounds and the process affected alveolar ducts and alveoli around the terminal bronchioles (Figure 1). The normal epithelium in these areas was replaced by cuboidal and columnar ciliated cells and some Clara cells and alveolar spaces were filled with PAS-positive material, suggestive of mucus (Figure 2). The incidences of bronchiolar metaplasia were increased in almost all chemical-treated groups except $44 \mathrm{ng} / \mathrm{kg}$ and lower PeCDF-dosed groups (Table 2). The incidences were higher than the control groups (0-9\%); 35, 62, 67, 85, and 88\% in all dosed groups treated with $\operatorname{TCDD}(3,10,22,46$, and $100 \mathrm{ng} / \mathrm{kg}$, respectively); 53, 64, 77, 74, 92, and $78 \%$ in all dosed groups treated with PCB126 $(30,100,175,300,550$, and $1000 \mathrm{ng} / \mathrm{kg}$, respectively); 17,43 , and $54 \%$ in 44,92 , and $200 \mathrm{ng} / \mathrm{kg}$ dosed groups treated with PeCDF. In the TEF mixture study, the incidence was increased at all dosed groups; 38, 62, 77, and 75\% in $10,22,46$, and $100 \mathrm{ngTEQ} / \mathrm{kg}$ treated groups. In the Stop-exposure groups the incidences of bronchiolar metaplasia decreased marginally in TCDD and PCB126 studies (62 and 64\%, respectively). In contrast, the incidence was markedly decreased in the Stop-exposure group of PeCDF study (14\%).

Squamous metaplasia occurred in small to large foci where normal alveolar epithelial structure was changed to a stratified squamous epithelium which often was highly keratinized (Figure 3). Alveolar wall structure, in general, was retained and some inflammation was present. Occasionally, squamous metaplasia and bronchiolar metaplasia occurred immediately adjacent to each other. The incidences of squamous metaplasia were increased in higher dosed groups treated with almost all chemicals (Table 2), compared to the incidences in control groups $(0-4 \%)$. The incidences were 9 and $12 \%$ in 46 and $100 \mathrm{ng} / \mathrm{kg}$ treated groups of TCDD, respectively; 6,18 , and $8 \%$ in 300,550 , and $1000 \mathrm{ng} / \mathrm{kg}$ treated groups of PCB 126 , respectively; 8 and $6 \%$ in 92 and $200 \mathrm{ng} / \mathrm{kg}$ treated groups of PeCDF, respectively. In the TEF mixture study, the incidence was also increased to $15 \%$ and $21 \%$ in 46 and $100 \mathrm{ngTEQ} / \mathrm{kg}$ treated groups. In the Stop-exposure groups treated with TCDD, PCB126 and PeCDF, the incidences of squamous metaplasia returned to control levels.

The incidences of alveolar epithelial hyperplasia were interestingly decreased in all treated groups of TCDD and PCB126 studies, compared to control groups (23 to 40\%). The decreased incidences of alveolar epithelial hyperplasia were also noted in the $92 \mathrm{ng} / \mathrm{kg}$ and greater dosed groups of the PeCDF study and in the $46 \mathrm{ngTEQ} / \mathrm{kg}$ and greater dosed groups of he TEF study. In the Stop groups treated with TCDD, PCB126 and PeCDF, the incidences of alveolar epithelial hyperplasia were not recovered to control levels.

Cystic keratinizing epitheliomas varied in size and number (single or multiple) and appeared as cystic structures consisting of a highly irregular wall of highly keratinized stratified squamous epithelium, with a center filled with keratin (Figures 4 and 5). The cystic keratinizing epithelioma had a thick complex wall with proliferative squamous epithelial outgrowths into surrounding alveolar spaces creating a cobblestone appearance to the outer perimeter of the 
mass (Figure 5). There was a lack of orderly transition of maturation of the wall, mitotic figures were sometimes present.

Both types of metaplasia, such as bronchiolar metaplasia and squamous metaplasia of alveolar epithelia seemed not to be associated with progression to neoplasia. Cystic keratinizing epithelioma (CKE) was not noted in control groups of any studies. The single and multiple cystic keratinizing epitheliomas were noted only in higher dosed groups of each study (Table 2); $17 \%$ in $100 \mathrm{ng} / \mathrm{kg}$ TCDD-treated group; 22 and $69 \%$ in 550 and $1000 \mathrm{ng} / \mathrm{kg}$ PCB126-treated groups, respectively; $2 \%$ in $200 \mathrm{ng} / \mathrm{kg}$ PeCDF-treated group; 4 and 38\% in 46 and $100 \mathrm{ngTEQ} /$ $\mathrm{kg}$ treated groups of TEF mixture study, respectively. The cystic keratinizing epitheliomas were not noted in any Stop groups treated with TCDD, PCB126 and PeCDF.

Squamous cell carcinomas demonstrated invasion of the surrounding lung parenchyma, loss of polarity, increased cellular atypia and pleomorphism, and an increased mitotic rate (Figure 6). These squamous cell carcinomas, considered as the malignant counterpart of cystic keratinizing epithelioma, were noted only in the 550 and $1000 \mathrm{ng} / \mathrm{kg}$ PCB126-treated groups as the incidences of $2 \%$ and $4 \%$, respectively (Table 2 ).

All data of pulmonary CYP1A1-associated 7-ethoxyresorufin-O-deethylase (EROD) activity at the 53-week interim groups of all compounds studies are summarized in Table 3. The control levels of pulmonary EROD were 1 to 3 pmol in each study. In contrast, levels of pulmonary EROD were increased much higher to 15-, 45-, 41-, and 27-fold at the magnitude, compared to each control group in the TCDD, PCB126, PeCDF, and TEF mixture studies, respectively. The EROD values of $10 \mathrm{ng} / \mathrm{kg}$ and greater TCDD-treated groups, $100 \mathrm{ng} / \mathrm{kg}$ and greater PCB126 treated groups, $20 \mathrm{ng} / \mathrm{kg}$ and greater PeCDF-treated groups, and all TEF mixturetreated groups showed values of $40 \mathrm{pmol}$ and above.

Dose-response parameters and relative potency factor (RPF) estimates for the induction of non neoplastic effects and pulmonary cytochrome P450 1A1, are shown in Table 4. Results for CKE from Walker et al. (2005) are shown for comparison purposes to the current analysis. In contrast to CKE, the non-neoplastic responses and P450 1A1 exhibited near linear doseresponse, as evidenced by Hill parameters in the range of 0.84-1.4. Of note was the $\mathrm{ED}_{50}$ for TCDD for the induction of P450 1A1 was similar to that for alveolar epithelial metaplasiabronchiolar (AEMB) but not for CKE or squamous metaplasia that occurred at much higher doses. Indeed AEMB was the most sensitive (lowest $\mathrm{ED}_{50}$ ) pulmonary response seen in these 2-year studies. Comparison of the dose response across chemical indicated that for the CYP1A1 and AEMB, but not squamous metaplasia, there were statistically significant differences in the shapes of the dose response between the individual studies. If data were modeled under the assumption of same shape, dose additivity of the mixture was rejected for AEMB and squamous metaplasia and CYP1A1 at 14 weeks.

\section{Discussion}

Cystic keratinizing epithelioma (CKE) has been generally perceived as a generic response of the rat lung toinstillation or inhalation of particulate materials (Boorman et al., 1996; Rittinghausen et al., 1997). Pulmonary cystic keratinizing lesions occur in the rat and are observed at a higher incidence in female rats (Boorman et al., 1996). An international workshop reviewed CKE and proposed a terminology and classification for cystic keratinizing squamous lesions (Boorman et al., 1996) using 18 rat inhalation studies; squamous cell metaplasia (SM), keratinizing cyst, CKE, squamous cell carcinoma (SCC). Additionally, Rittinghausen and coauthors (1997) reclassified SM with marked keratinization, keratinizing cyst, CKE, cystic keratinizing SCC, keratinizing SCC, and non-keratinizing SCC. Using 4 rat inhalation studies, they examined the lesions immunohisto-chemically for proliferating cell nuclear antigen 
(PCNA). PCNA staining demonstrated proliferative activity in one or two peripheral cell layers of CKE (and sometimes focally more than two layers), in more than three peripheral cell layers of cystic keratinizing SCC and keratinizing SCC, and in no peripheral cells or a weak reaction of the wall of keratinizing cysts. Generally, CKE has been perceived as occurring at relatively low incidence (up to $20 \%$ ), rarely before 20 months on study, occuring only at high exposures to inhaled particulates, rarely seen as a spontaneous lesion in rats, and not seen in mice or hamsters (Rittinghausen et al., 1997; Rittinghausen and Kaspareit, 1998).

The uniqueness of the present report is the fact that the pulmonary squamous proliferative lesions developed following oral exposure. In general, squamous metaplasia with some inflammation is increased in higher-dosed groups after inhalation exposure with several chemicals(Lee et al., 1986, Notle et al;. 1996). This change is considered a common form of cellular adaptation to injury and tends to be associated with the significant forms of injury (Lee and Henry, 1986; Nolte et al., 1996). Squamous metaplasia is also a consistent finding in rats fed a vitamin A deficient diet (Alexander and Bancewicz, 1988). In human SM is also a common reaction to injury, toxins, and vitamin A deprivation (Basbaum and Jany, 1990).

In the 2-year feed study by Kociba et al. (1978), an increased incidence of keratinizing SCC of the lung was observed following exposure to $100 \mathrm{ng} / \mathrm{kg}$ TCDD. While no direct comparison has been made between CKE and the keratinizing SCC observed in the Kociba et al. (1978) study, given the keratinizing nature of the CKE it is possible that these represent the same lesions. Indeed neoplastic lesions induced by inhalation exposure to $\mathrm{TiO}_{2}$, were also diagnosed as SCC. These lesions would likely be diagnosed nowadays as CKE (Lee and Henry, 1986).

While there is clear induction of CKE by PCB126, there have not been any cancer bioassays of individual PCB congeners before these current NTP studies and interestingly there have not been any reports that PCB mixtures induce pulmonary tumors in any rodent carcinogenesis studies. In contrast to the present study, the carcinogenicity study of the high TEQ PCB mixture Aroclor 1254 in SD rats demonstrated no increases in any type of lung tumor (Mayes et al., 1998). While Aroclor 1254 contains a significant TEQ contribution by coplanar PCBs that have dioxin like activity, this mixture also contains mono-ortho and di-ortho PCBs. Several researchers reported that PCBs (Kanechlor-400) promoted 1-nitropyrene-induced lung tumorigenesis in mice (Nakanishi et al., 1999, 2001) and PCBs (Aroclor-1254) promoted Nnitrosodimethylamine-induced lung tumorigenesis in mice (Abderson et al., 1994). It is very notable that the effects of PCBs on human lung carcinogenesis are suggested from the massive PCBs poisoning that occurred in "Yusho accident" and "Yu-Cheng Accident" (ATSDR, 2000; Kikuchi, 1984; Nakanishi and Shigematsu, 1991) whereby individuals consumed PCB contaminated cooking oil. However it is not known what types of tumors were induced in these PCB-exposed individuals.

There was a significant increase in the incidences of bronchiolar metaplasia of the alveolar epithelium at all doses at two years in all studies including the stop-exposure groups. These findings are consistent with prior observations of an increase in the incidences of alveolarbronchiolar metaplasia following exposure to TCDD within the framework of a two stage initiation-promotion model in SD rat lung (Tritscher et al., 2000). This lesion was induced multi-focally throughout the lung at the junction of the terminal bronchioles and alveolar ducts. The epithelium was cuboidal to columnar, and ciliated in contrast to type II alveolar epithelial cells. Also, scattered throughout the ciliated cells were dome-shaped non-ciliated cells, consistent with Clara cells, which are normally found in the lining of the bronchioles, but not alveoli or alveolar ducts. Histochemical analyses of mucin and immuno-histochemically for glutathione S-transferase Pi (GSTPi) in lung tissue from our studies indicates that this does appear to be similar to bronchiolar epithelium and is distinct from alveolar epithelial hyperplasia (Brix et al., 2003). 
In TCDD and PCB126 studies, the higher incidences (23 to 26\%) of alveolar epithelial hyperplasia were only observed in vehicle control animals. Interestingly, the decreased incidences of alveolar epithelial hyperplasia were noted in all dosed groups of TCDD and PCB126 studies, in higher-dosed groups of PeCDF and TEF studies. Alveolar ducts and alveoli are normally lined by type I alveolar epithelial cells and type II alveolar epithelial cells. Type I cells are very susceptible to damage and the typical response in the lung, subsequent to the damage to the type I cells is a proliferation of the type II cells. In alveolar epithelial hyperplasia, alveoli are lined by alveolar type II epithelium and unlike bronchiolar metaplasia in treated animals, prominent mucus production was not observed. In addition a prominent inflammatory cell infiltrate, consisting of large aggregates of alveolar macrophages commonly mixed with focal aggregates of neutrophils, was usually associated with the affected areas (data not shown). The reduced incidence of this change in TCDD- and DLCs-treated animals might be the secondary effect to the immunosuppres-sive effect of these compounds, i.e., reducing the extent of the "spontaneous" inflammatory reaction, commonly seen in untreated controls.

The aryl hydrocarbon receptor is a ligand-activated transcription factor that mediates the biological and toxicological effects of TCDD and related DLCs (Poland et al., 1982; Schmidt and Bradfield, 1996; Denison and Nagy, 2003). It is expressed ubiquitously in human and rodent systemic organs, particularly in the lung, (Dolwick et al., 1993; Yamamoto et al., 2004). In the rat the AhR is expressed in the bronchiolar Clara cells and cilated cells (Tritscher et al., 2000). That most organs with AhR expression are thought to be more susceptible to TCDD-induced toxicity is evidenced by AhR-deficient mice that are resistant to some kinds of TCDD-induced toxicity (Fernandez-Salguero et al., 1996; Gonzalez and FernandezSalguero, 1998). The most well-studied response to TCDD is induction of the CYP1 class of cytochrome P450 (Denison and Nagy, 2003; Schmidt and Bradfield, 1996) regulated by the AhR (Nebert et al., 2004; Vrzal et al., 2004). CYP1A1 is also known to be inducible in the lung by TCDD in several species (Beebe et al., 1990). This was confirmed in our TCDD, PCB126, PeCDF, and TEF mixture studies by the observed increase in lung CYP1A1 associated EROD activities. The induction of CYP1A1 by TCDD is observable in Clara cells and bronchiolar cells, and to a lesser degree in type II alveolar epithelial cells (Tritscher et al., 2000), indicating that the bronchiolar epithelium is clearly responsive to AhR ligands and suggesting the potential for a direct effect of TCDD on the lung. In vitro studies of normal human lung epithelial cells (mixed Type II, Clara cell type) also demonstrate the altered expression by TCDD of genes involved in numerous cell signaling pathways, indicative of altered retinoid signaling and altered cytokine signaling pathways (Martinez et al., 2002).

A possible mechanism for the action of TCDD and other DLCs on the lung, especially induction of CKE, may be an indirect effect due to the disruption of retinoid homeostasis in the liver by these compounds. It is known that in rodents, mobilization of retinoid stores by TCDD and DLCs leads to a disruption in retinoid homeostasis and vitamin A deficiency (Van Birgelen et al., 1994, 1995; Fattore et al., 2000; Schmidt et al., 2003), especially in the liver and lung (Fiorella et al., 1995; Fletcher et al., 2001; Hakansson et al., 1991). Microsomes from several tissues of rats 3 days after a single exposure to TCDD, exhibited increased rates of retinoic acid metabolism with the degree of induction following the order: liver $>$ lung = kidney $=$ testis (Fiorella et al., 1995). Hepatic and pulmonary vitamin A is reduced in rats following dietary exposure to TCDD and PCB126 for 13 weeks (Hakansson et al., 1994). A characteristic of retinoid deficiency is abnormal epithelial differentiation to a keratinized squamous phenotype (Lancillotti et al., 1992; Lotan, 1994). The action of DLC may, therefore, be a disruption of retinoid action leading to altered growth and differentiation of the lung epithelium resulting in squamous metaplasia and CKE. Of note was that in our studies, TCDD, PCB126, PeCDF, and TEF mixture affected the epithelial differentiation to squamous type; the induction of gingival squamous cell hyperplasia and/or SCC, endometrial squamous metaplasia and/or SCC, and squamous hyperplasia in forestomach (NTP 2004a, b, c, d; Yoshizawa et al., 2005). 
Carbon black, $\mathrm{TiO} 2$, and diesel engine exhaust induce benign cystic keratinizing squamous cell tumors in rat inhalation studies (Lee et al., 1986; Mohr et al., 1986; Rausch et al., 2004). Rausch and coauthors (2004) concluded that this species-specific response (tumor formation and cystic lesions) by the rat to carbon black strongly suggests that the results of the rat inhalation bioassay should not be considered directly relevant when assessing human risk, as these lesions were not seen in any other animal studies and in humans, lung tumors in humans are primarily located in the bronchial airways, while in the rat they occur in the parenchyma and are alveolar in origin. If the only evidence of tumorigenicity is the presence of CKE, it may not have relevance to human safety evaluation of chemicals (Boorman et al., 1996). In our studies there was an increase in both CKE and SCC. Additionally, TCDD is also a tumor promoter in the rodent lungs of male Swiss mice and female SD rats initiated with nitrosodimethylamine (Beebe et al., 1995; Tritscher et al., 2000). In humans, exposures to high levels of TCDD and DLCs are associated with chronic obstructive pulmonary disease and lung cancer (ATSDR, 2000; Fingerhut et al., 1991; Kikuchi, 1984; Nakanishi and Shigematsu, 1991; Zober et al., 1994, 1997/1998; Reggiani, 1980). Therefore, this mightsuggest that the evidence of pulmonary carcinogenicity of TCDD and DLCs in our NTP studies has relevance to human lung tumor risk of these chemicals.

In conclusion, the exposure to TCDD, PCB126, PeCDF, and the TEF mixture of TCDD, PCB 126 and PeCDF for 2 years in rats induced pulmonary lesions, such as bronchiolar metaplasia of the alveolar epithelium, squamous metaplasia of the alveolar epithelium, cystic keratinizing epithelioma, and/or squamous cell carcinoma, probably via CYP1A1 induction in pulmonary epithelial cells and/or via pulmonary retinoid deficiency resulting in abnormal epithelial differentiation. Further research analyzing the mechanism of action and focusing on molecular function could enhance our understanding of the pathogenesis, and provide insight into the risk assessment to humans of dioxin and DLC-induced pulmonary carcinogenesis.

\section{Acknowledgments}

The authors thank all involved in the design and conduct of these NTP studies, with special appreciation expressed to John Bucher, Angelique Braen, Milton Hejtmancik and Ms. Denise Orzech. We gratefully acknowledge Helen Cunny, Mark Cesta, and JoAnne Johnson for critical review of the manuscript and Mr. Norris Flagler for expert preparation of the illustrations. The authors declare that they have no competing financial interests. This research was supported by the Intramural Research Program of the NIEHS, NIH.

\section{Abbreviations}

AEMB, Alveolar epithelium, metaplasia, bronchiolar

AhR, aryl hydrocarbon receptor

CKE, cystic keratinizing epithelioma

CYP, cytochrome P450

DLC, dioxin-like compound

EROD, -ethoxyresorufin-O-deethylase

GSTPi, glutathione S-transferase Pi

H\&E, 7-hematoxylin and eosin

IARC, International Agency for Research on Cancer

NTP, National Toxicology Program

PCB126, 3,3',4,4',5-pentachlorobiphenyl

PCDDs, polychlorinated dibenzodioxins

PCDFs, polychlorinated dibenzofurans

PCNA, proliferating cell nuclear antigen

PeCDF, 2,3,4,7,8-pentachloro-dibenzofuran

SCC, squamous cell carcinoma

SM, squamous metaplasia 
TCDD, 2,3,7,8-tetrachlorodibenzo-p-dioxin

TEF, toxic equivalency factor

TEQ, toxic equivalent

WHO, World Health Organization

\section{References}

Agency for Toxic Substances and Disease Registry (ATSDR). Toxicological Profile for Chlorinated Dibenzo-p-dioxins. Agency for Toxic Substances and Disease Registry; Atlanta, GA: 1998.

Agency for Toxic Substances and Disease Registry (ATSDR). Toxicological Profile for Polychlorinated Biphenyls (PCBs). Agency for Toxic Substances and Disease Registry; Atlanta, GA: 2000.

Alexander A, Bancewicz J. Vitamin A deficiency and resistance to infection in experimental animals. Surg Res Commun 1988;4/3:257-67.

Anderson LM, Logsdon D, Ruskie S, Fox SD, Issaq HJ, Kovatch RM, Riggs CM. Promotion by polychlorinated biphenyls of lung and liver tumors in mice. Carcinogenesis 1994;15:2245-8. [PubMed: 7955061]

Basbaum C, Jany B. Plasticity in the airway epithelium. Am J Physiol 1990;259:L38-46. [PubMed: 2200283]

Beebe LE, Anver MR, Riggs CW, Fornwald LW, Anderson LM. Promotion of N-nitrosodimethylamineinitiated mouse lung tumors following single or multiple low dose exposure to 2,3,7,8tetrachlorodibenzo-p-dioxin. Carcinogenesis 1995;16:1345-9. [PubMed: 7788853]

Beebe L, Park SS, Anderson LM. Differential enzyme induction of mouse liver and lung following a single low or high dose of 2,3,7,8-tetrachlorodibenzo-p-dioxin (TCDD). J Biochem Toxicol 1990;5:211-9. [PubMed: 2096217]

Bertazzi PA, Consonni D, Bachetti S, Rubagotti M, Baccarelli A, Zocchetti C, Pesatori ACl. Health effects of dioxin exposure: a 20-year mortality study. Am J Epidemiol 2001;153:1031-44. [PubMed: 11390319]

Boorman GA, Brockmann M, Carlton WW, Davis JMG, Dungworth DL, Hahn FF, Mohr U, Reichhelm HBR, Turusov VS, Wagner BM. Classification of cystic keratinizing squamous lesions of the rat lung: report of a workshop. Toxicol Pathol 1996;24:564-72. [PubMed: 8923677]

Boorman, GA.; Hailey, R. Squamous Cell Carcinoma, Lung, Rat. In: Jones, TC.; Dungworth, DL.; Mohr, U., editors. Respiratory System. Vol. Second Edition. Springer; New York: 1996. p. 207-12.

Boorman GA, Haseman JK, Waters MD, Hardisty JF, Sills RC. Quality review procedures necessary for rodent pathology databases and toxicogenomic studies: The National Toxicology Program experience. Toxicol Pathol 2002;30:88-92. [PubMed: 11890481]

Brix AE, Jokinen MP, Walker NJ, Sells DM, Nyska A. Characterization of bronchiolar metaplasia of the alveolar epithelium in female Sprague-Dawley rats exposed to 3,3',4,4' 5-pentachlorobiphenyl (PCB126). Toxicol Pathol 2004;32:333-7. [PubMed: 15204975]

Denison MS, Nagy SR. Activation of the aryl hydrocarbon receptor by structurally diverse exogenous and endogenous chemical. Annu Rev Pharmacol Toxicol 2003;43:309-34. [PubMed: 12540743]

Dolwick KM, Schmidt JV, Carver LA, Swanson HI, Bradfield CA. Cloning and expression of a human Ah receptor cDNA. Mol Pharmacol 1993;44:911-7. [PubMed: 8246913]

Dunn OJ. Multiple comparisons using rank sums. Technometrics 1964;6:241-52.

Fattore E, Trossvik C, Hakansson H. Relative potency values derived from hepatic vitamin A reduction in male and female Sprague-Dawley rats following subchronic dietary exposure to individual polychlorinated dibenzo-p-dioxin and dibenzofuran congeners and a mixture thereof. Toxicol Appl Pharmacol 2000;165:184-94. [PubMed: 10860868]

Fernandez-Salguero PM, Hilbert DM, Rudikoff S, Ward JM, Gonzalez FJ. Aryl-hydrocarbon receptordeficient mice are resistant to 2,3,7,8-tetrachlorodibenzo-p-dioxin-induced toxicity. Toxicol Appl Pharmacol 1996;140:173-9. [PubMed: 8806883]

Fingerhut MA, Halperin WE, Marlow DA, Piacitelli LA, Honchar PA, Sweeney MH, Greife AL, Dill PA, Steenland K, Suruda AJ. Cancer mortality in workers exposed to 2,3,7,8-tetrachlorodibenzo- $p$ dioxin. N Engl J Med 1991;324:212-18. [PubMed: 1985242] 
Fiorella PD, Olson JR, Napoli JL. 2,3,7,8-Tetrachlorodibenzo- $p$-dioxin induces diverse retinoic acid metabolites in multiple tissues of the Sprague-Dawley rat. Toxicol Appl Pharmacol 1995;134:2228. [PubMed: 7570598]

Fletcher N, Hanberg A, Hakansson H. Hepatic vitamin A depletion is a sensitive marker of 2,3,7,8tetrachlorodibenzo-p-dioxin (TCDD) exposure in four rodent species. Toxicol Sci 2001;62:166-75. [PubMed: 11399804]

Gonzalez FJ, Fernandez-Salguero P. The aryl hydrocarbon receptor. Studies using the AHR-null mice. Drug Metab Dispos 1998;26:1194-8. [PubMed: 9860927]

Hakansson H, Johansson L, Manzoor E, Ahlborg UG. Effects of 2,3,7,8-tetrachlorodibenzo-p-dioxin (TCDD) on the vitamin A status of Hartley guinea pigs, Sprague-Dawley rats, C57B1/6 mice, DBA/ 2 mice, and Golden Syrian hamsters. J Nutr Sci Vitaminol (Tokyo) 1991;37:117-38. [PubMed: 1919800]

Hakansson H, Manzoor E, Trossvik C, Ahlborg UG, Chu I, Villenueve D. Effect on tissue vitamin A levels in the rat following subchronic exposure to four individual PCB congeners (IUPAC 77, 118, 126, and 153). Chemosphere 1994;29:2309-13. [PubMed: 7850379]

International Agency for Research on Cancer (IARC). IARC Monogr Eval Carcinog Risks Hum. Vol. 69. Lyon, France: 1997. IARC working group on the evaluation of carcinogenic risks to humans: polychlorinated dibenzo-para-dioxins and polychlorinated dibenzofurans; p. 1-631.

Jokinen MP, Walker NJ, Brix AE, Sells DM, Haseman JK, Nyska A. Increase in cardiovascular pathology in female Sprague-Dawley rats following chronic treatment with 2,3,7,8-tetrachlorodibenzo- $p$-dioxin and 3,3,'4,4'5-pentachlorobiphenyl. Cardiovasc Toxicol 2003;3:299-310. [PubMed: 14734827]

Kikuchi M. Autopsy of patients with yusho. Prog Clin Biol Res 1984;137:19-30. [PubMed: 6425851]

Kociba RJ, Keyes DG, Beyer JE, Carreon RM, Wade CE, Dittenber DA, Kalnins RP, Frauson LE, Park CN, Barnard SD, Hummel RA, Humiston CG. Results of a two-year chronic toxicity and oncogenicity study of 2,3,7,8-tetrachlorodibenzo-p-dioxin in rats. Toxicol Appl Pharmacol 1978;46:279-303. [PubMed: 734660]

Lancillotti F, Darwiche N, Celli G, De Luca LM. Retinoid status and the control of keratin expression and adhesion during the histogenesis of squamous metaplasia of tracheal epithelium. Cancer Res 1992;52:6144-52. [PubMed: 1384955]

Lee KP, Henry NW 3rd, Trochimowics HJ, Reinhardt CF. Pulmonary response to impaired lung clearance in rats following excessive TiO2 dust deposition. Environ Res 1986;41:144-167. [PubMed: 3757966]

Lotan R. Suppression of squamous cell carcinoma growth and differentiation by retinoids. Cancer Res 1994;54:1987s-90s. [PubMed: 8137325]

Martinez JM, Afshari CA, Bushel PR, Masuda A, Takahashi T, Walker NJ. Differential toxicogenomic responses to 2,3,7,8-tetrachlorodibenzo- $p$-dioxin in malignant and nonmalignant human airway epithelial cells. Toxicol Sci 2002;69:409-23. [PubMed: 12377990]

Mayes BA, McConnell EE, Neal BH, Brunner MJ, Hamilton SB, Sullivan TM, Peters AC, Ryan MJ, Toft JD, Singer AW, Brown JF Jr, Menton RG, Moore JA. Comparative carcinogenicity in SpragueDawley rats of the polychlorinated biphenyl mixtures Aroclors 1016, 1242, 1254, and 1260. Toxicol Sci 1998;41:62-76. [PubMed: 9520342]

Mohr U, Takenaka S, Dungworth DL. Morphologic effects of inhaled diesel engine exhaust on lungs of rats: comparison with effects of coal oven flue gas mixed with pyrolyzed pitch. Dev Toxicol Environ Sci 1986;13:459-470. [PubMed: 2435503]

Nakanishi Y, Bai F, Inoue K, Takayama K, Pei XH, Harada T, Izumi M, Kimotsuki K, Tokiwa H, Hara N. Polychlorinated biphenyls promote 1-nitropyrene-induced lung tumorigenesis without the induction of K-ras gene mutation in A/J mice. Teratog Carcinog Mutagen 2001;21:395-403. [PubMed: 11746253]

Nakanishi Y, Bai F, Takayama K, Pei XH, Inoue K, Osaki S, Izumi M, Takaki Y, Hara N, Tokiwa H, Masuda Y. Effect of PCBs on mouse lung tumorigenesis induced by 1-nitropyrene: a preliminary report. Fukuoka Igaku Zasshi 1999;90:231-7. [PubMed: 10396879]

Nakanishi Y, Shigematsu N. Carcinogenic effects of polychlorinated biphenyls (PCBs) and their derivatives, including carcinogenicity to the lung. Fukuoka Igaku Zasshi 1991;82:251-55. [PubMed: 1916596] 
National Toxicology Program (NTP). Female Harlan Sprague-Dawley Rats (Gavage Studies). National Toxicology Program; Research Triangle Park, NC: 2004a. Toxicology and Carcinogenesis Studies of a Mixture of 2,3,7,8-Tetrachlorodibenzo- $p$-dioxin (TCDD) (CAS No. 1746-01-6), 2,3,4,7,8Pentachlorodibenzofuran (PeCDF) (CAS No. 57117-31-4), and 3,3',4,4',5-Pentachlorobiphenyl (PCB126) (CAS No. 57465-28-8). Technical Report 526

National Toxicology Program (NTP). Female Harlan Sprague-Dawley Rats (Gavage Studies). National Toxicology Program; Research Triangle Park, NC: 2004b. Toxicology and Carcinogenesis Studies of 3,3',4,4',5-Pentachlorobiphenyl (PCB126) (CAS No. 57465-28-8). Technical Report 520

National Toxicology Program (NTP). Female Harlan Sprague-Dawley Rats (Gavage Studies). National Toxicology Program; Research Triangle Park, NC: 2004c. Toxicology and Carcinogenesis Studies of 2,3,4,7,8-Pentachlorodibenzofuran (PeCDF) (CAS No. 57117-31-4). Technical Report 525

National Toxicology Program (NTP). Female Harlan Sprague-Dawley Rats (Gavage Studies). National Toxicology Program; Research Triangle Park, NC: 2004d. Toxicology and Carcinogenesis Studies of 2,3,7,8-Tetrachloribenzo-p-dioxin (TCDD) (CAS No. 1746-01-6). Technical Report 521

Nebert DW, Dalton TP, Okey AB, Gonzalez FJ. Role of aryl hydrocarbon receptor-mediated induction of the CYP1 enzymes in environmental toxicity and cancer. J Biol Chem 2004;279:23847-50. [PubMed: 15028720]

Nolte, T.; Ernst, H.; Dungworth, DL. Squamous Metaplasia, Lung, Rat. In: Jones, TC.; Dungworth, DL.; Mohr, U., editors. Respiratory System. Vol. Second Edition. Springer; New York: 1996. p. 285-292.

Nyska A, Jokinen MP, Brix AE, Sells DM, Wyde ME, Orzech DP, Haseman JK, Flake G, Walker NJ. Exocrine pancreatic pathology in female Harlan Sprague-Dawley rats after chronic treatment with 2,3,7,8-tetrachlorodibenzo- $p$-dioxin and dioxin-like compounds. Environ Health Perspect 2004;112:903-9. [PubMed: 15175180]

Nyska A, Yoshizawa K, Jokinen MP, Brix AE, Sells DM, Wyde ME, Orzech DP, Kissling GE, Walker NJ. Olfactory epithelial metaplasia and hyperplasia in female Harlan Sprague-Dawley rats following chronic treatment with polychlorinated biphenyls. Toxicol Pathol 2005;33:371-7. [PubMed: 15805076]

Pesatori AC, Consonni D, Bachetti S, Zocchetti C, Bonzini M, Baccarelli A, Bertazzi PA. Short- and long-term morbidity and mortality in the population exposed to dioxin after the "Seveso accident". Ind Health 2003;41:127-38. [PubMed: 12916742]

Poland A, Knutson JC. 2,3,7,8-tetrachlorodibenzo-p-dioxin and related halogenated aromatic hydrocarbons: examination of the mechanism of toxicity. Annu Rev Pharmacol Toxicol 1982;22:517-54. [PubMed: 6282188]

Rausch LJ, Bisinger EC Jr. Sharma A. Carbon black should not be classified as a human carcinogen based on rodent bioassay data. Regul Toxicol Pharmacol 2004;40:28-41. [PubMed: 15265604]

Reggiani G. Acute human expose to TCDD in Seveso, Italy. J Toxicol Environ Health 1980;6:27-43. [PubMed: 7381973]

Rittinghausen S, Kaspareit J. Spontaneous cystic keratinizing epithelioma in the lung of a SpragueDawley rat. Toxicol Pathol 1998;26:298-300. [PubMed: 9547872]

Rittinghausen S, Mohr U, Dungworth DL. Pulmonary cystic keratinizing squamous cell lesions of rats after inhalation/instillation of different particles. Exp Toxicol Pathol 1997;49:433-46. [PubMed: 9495643]

Schmidt JV, Bradfield CA. Ah receptor signaling pathway. Annu Rev Cell Dev Biol 1996;12:55-89. [PubMed: 8970722]

Schmidt CK, Hoegberg P, Fletcher N, Nilsson CB, Trossvik C, Hakansson H, Nau H. 2,3,7,8tetrachlorodibenzo- $p$-dioxin (TCDD) alters the endogenous metabolism of all-trans-retinoic acid in the rat. Arch Toxicol 2003;77:371-83. [PubMed: 12851740]

Sells DM, Brix AE, Nyska A, Jokinen MP, Orzech DP, Walker NJ. Respiratory tract lesions in noninhalation studies. Toxicol Pathol 2007;35:170-7. [PubMed: 17325986]

Shirley E. A non-parametric equivalent of William's test for contrasting increasing dose levels of a treatment. Biometrics 1977;33:386-389. [PubMed: 884197]

Steenland K, Deddens J, Piacitelli L. Risk assessment for 2,3,7,8-tetrachlorodibenzo- $p$-dioxin (TCDD) based on an epidemiologic study. Am J Epidemiol 2001;154:451-8. [PubMed: 11532787] 
Tani Y, Maronpot RR, Foley JF, Haseman JK, Walker NJ, Nyska A. Follicular epithelial cell hypertrophy induced by chronic oral administration of 2,3,7,8-tetrachlorodibenzo- $p$-dioxin in female Harlan Sprague-Dawley rats. Toxicol Pathol 2004;32:41-9. [PubMed: 14713547]

Tritscher AM, Mahler J, Portier CJ, Lucier GW, Walker NJ. Induction of lung lesions in female rats following chronic exposure to 2,3,7,8-tetrachlorodibenzo-p-dioxin. Toxicol Pathol 2000;28:761769. [PubMed: 11127289]

Tusscher GWT, Koppe JG. Perinatal dioxin exposure and later effects-a review. Chemosphere 2004;54:1329-1336. [PubMed: 14659426]

Van Birgelen AP, Van der Kolk J, Fase KM, Bol I, Poiger H, Brouwer A, Van den Berg M. Toxic potency of 3,3',4,4',5-pentachlorobiphenyl relative to and in combination with 2,3,7,8-tetrachlorodibenzo- $p$ dioxin in a subchronic feeding study in the rat. Toxicol Appl Pharmacol 1994;127:209-21. [PubMed: 8048064]

Van Birgelen AP, Van der Kolk J, Fase KM, Bol I, Poiger H, Brouwer A, Van den, Berg M. Subchronic dose-response study of 2,3,7,8-tetrachlorodibenzo-p-dioxin in female Sprague-Dawley rats. Toxicol Appl Pharmacol 1995;132:1-13. [PubMed: 7747272]

Van den Berg M, Birnbaum L, Bosveld ATC, Brunstrom B, Cook P, Feeley M, Giesy JP, Hanberg A, Hasegawa R, Kennedy SW, Kubiak T, Larsen JC, van Leeuwen FX, Liem AK, Nolt C, Peterson RE, Poellinger L, Safe S, Schrenk D, Tillitt D, Tysklind M, Younes M, Waern F, Zacharewski T. Toxic equivalency factors (TEFs) for PCBs, PCDDs, PCDFs for humans and wildlife. Environ Health Perspect 1998;106:775-92. [PubMed: 9831538]

Vrzal R, Ulrichova J, Dvorak Z. Aromatic hydrocarbon receptor status in the metabolism of xenobiotics under normal and pathophysiological conditions. Biomed Pap 2004;148:3-10.

Walker NJ, Crockett PW, Nyska A, Brix AE, Jokinen MP, Sells DM, Hailey JR, Easterling M, Haseman JK, Yin M, Wyde ME, Bucher JR, Portier CJ. Dose-additive carcinogenicity of a defined mixture of “dioxin-like compounds”. Environ Health Perspect 2005;113:43-8. [PubMed: 15626646]

Walker NJ, Wyde ME, Fischer LJ, Nyska A, Bucher JR. Comparison of chronic toxicity and carcinogenicity of 2,3,7,8-tetrachlorodibenzo-p-dioxin (TCDD) in two-year bioassays in female Sprague-Dawley rats. Mol. Nutr. Food Res 2006;50:934-944. [PubMed: 16977594]

Williams DA. A note on Shirley's nonparametric test for comparing several dose levels with a zero-dose control. Biometrics 1986;42:183-186. [PubMed: 3719054]

Yamamoto J, Ihara K, Nakayama H, Hikino S, Satoh K, Kubo N, Iida T, Fujii Y, Hara T. Characteristics expression of aryl hydrocarbon receptor receptor repressor gene in human tissues: organspecificdistribution and variable induction patterns in mononuclear cells. Life Sciences 2004;74:1039-49. [PubMed: 14672759]

Yoshizawa K, Marsh T, Foley JF, Cai B, Peddada S, Walker NJ, Nyska A. Mechanisms of exocrine pancreatic toxicity induced by oral treatment with 2,3,7,8-tetrachlorodibenzo-p-dioxin in female Harlan Sprague-Dawley rats. Toxicol Sci 2005;85:594-606. [PubMed: 15716480]

Yoshizawa K, Walker NJ, Jokinen MP, Brix AE, Sells DM, Marsh T, Wyde ME, Orzech D, Haseman JK, Nyska A. Gingival carcinogenicity in female Harlan Sprague-Dawley rats following two-year oral treatment with 2,3,7,8-tetrachlorodibenzo- $p$-dioxin and dioxin-like compounds. Toxicol Sci 2005a;83:64-77. [PubMed: 15509667]

Zober A, Messerer P, Ott MG. BASF studies: epidemiological and clinical investigations on dioxinexposed chemical workers. Teratogenesis Carcinog Mutagen 199798;17:249-56. [PubMed: 9508734]

Zober A, Ott MG, Messerer P. Morbidity follow up study of BASF employees exposed to 2,3,7,8tetrachlorodibenzo-p-dioxin (TCDD) after 1953 chemical reactor incident. Occup Environ Med 1994;51:479-86. [PubMed: 8044248] 


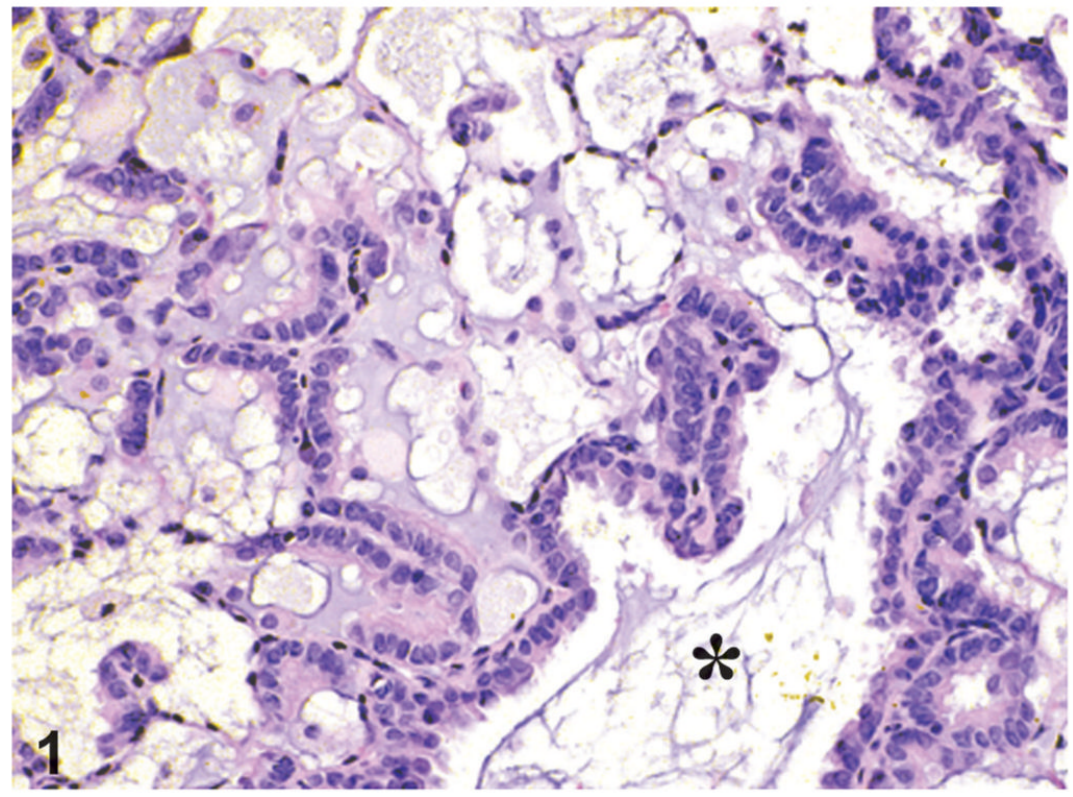

Figure 1.

Bronchiolar metaplasia of alveolar epithelium is present at the junction of terminal bronchioles (*) and alveolar ducts throughout lung. Alveolar type I cells have been replaced by cuboidal to columnar ciliated cells. Scattered among these cells are cells that lack cilia and have a smooth apical surface that protrudes into alveolar duct space. TEF Mixture study, H\&E, x20. 


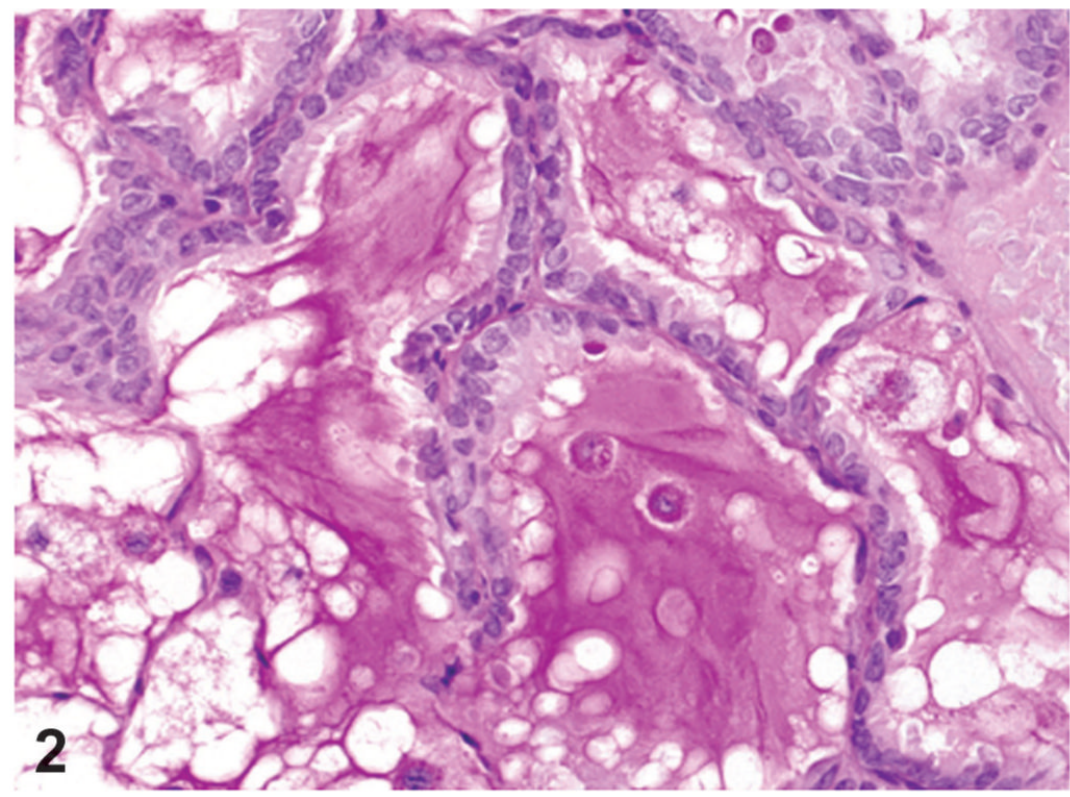

Figure 2.

Bronchiolar metaplasia of alveolar epithelium. In alveolar lumens abundant Periodic acidSchiff (PAS)-positive materials, consistent with mucus, can be seen. PCB126 study, PAS staining, X100. 


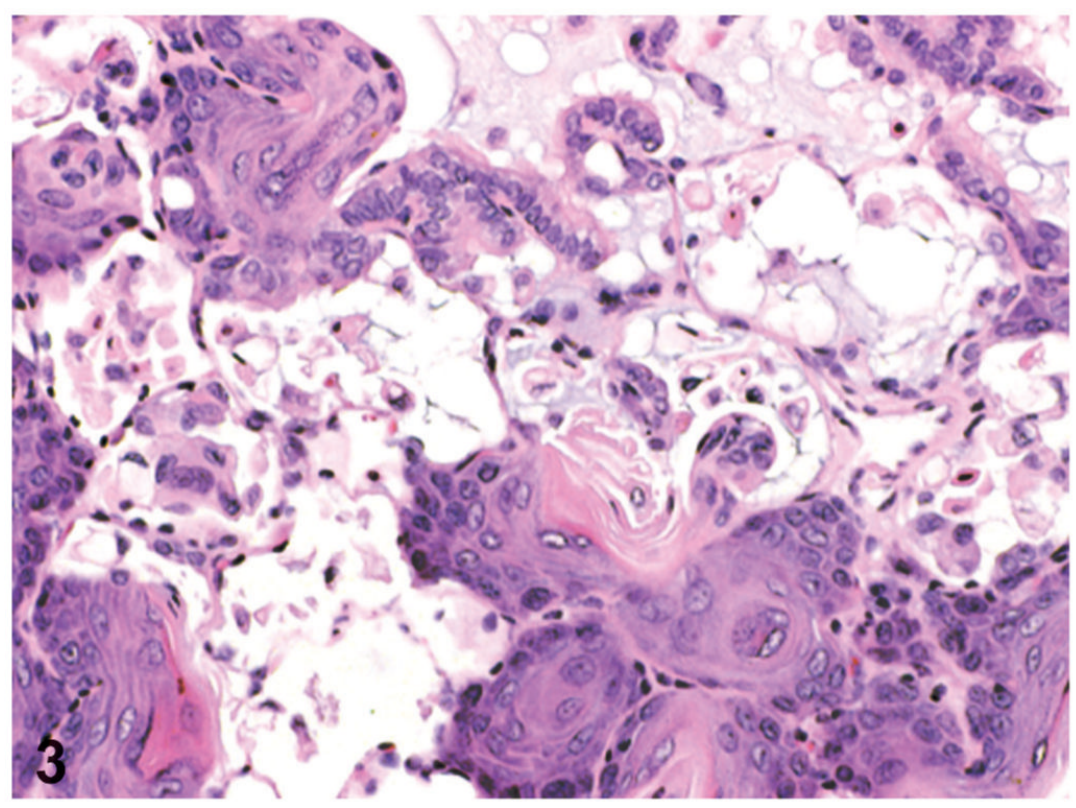

Figure 3.

Squamous metaplasia of alveolar epithelium. This lesion is located in small to large foci where the normal alveolar epithelial structure was changed to a stratified squamous epithelium with keratinization. PCB126 study, H\&E, X66. Reprinted with permission from Toxicologic Pathology from Sells et al. 2007. 


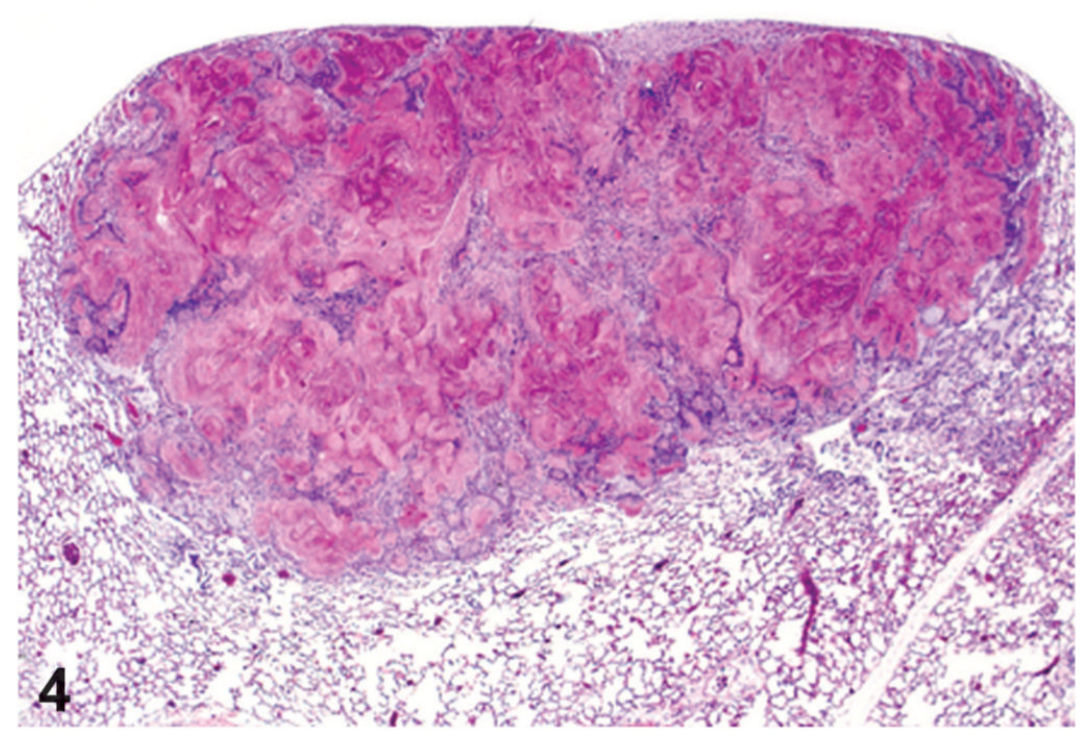

Figure 4.

Cystic keratinizing epithelioma. The mass is located in the lung below the thoracic serosa and has a center filled with keratin. TCDD study, H\&E, X5. 


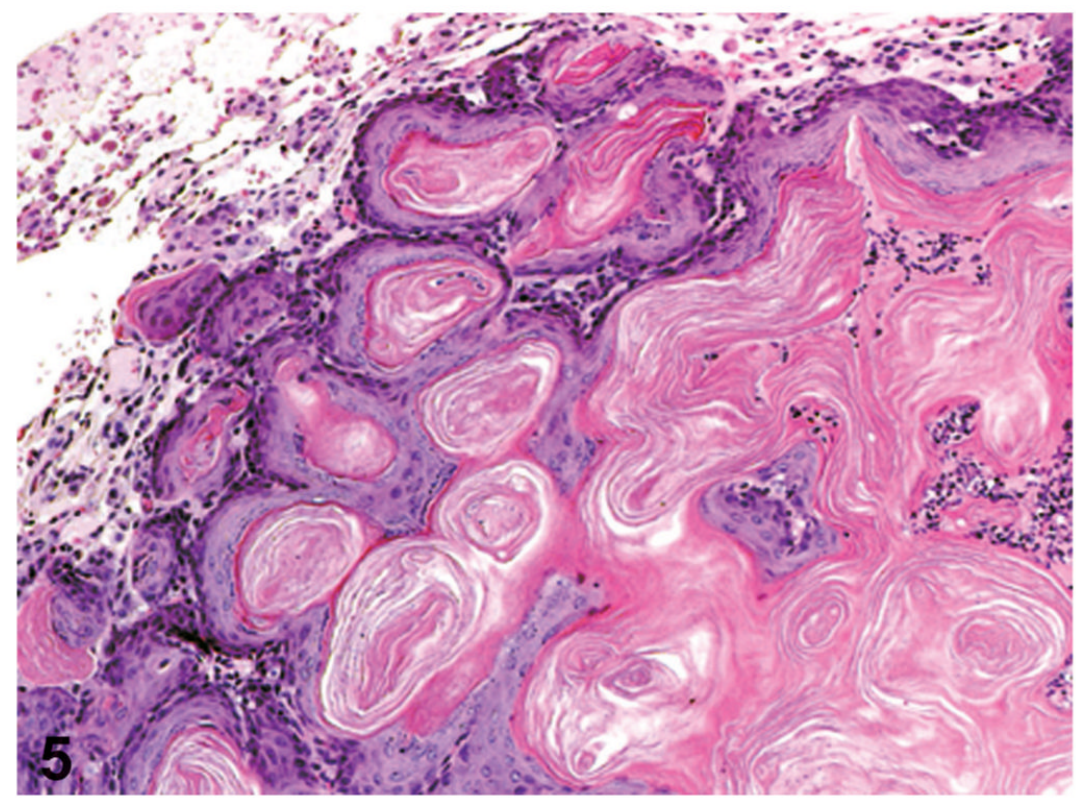

Figure 5.

Cystic keratinizing epithelioma. Cystic structures consists of a highly irregular wall of highly keratinized stratified squamous epithelium, with a center filled with keratin. The wall has a thick complex proliferation of squamous epithelial outgrowths into surrounding alveolar spaces. PCB126 study, H\&E, X33. Reprinted with permission from Toxicologic Pathology from Sells et al. 2007. 


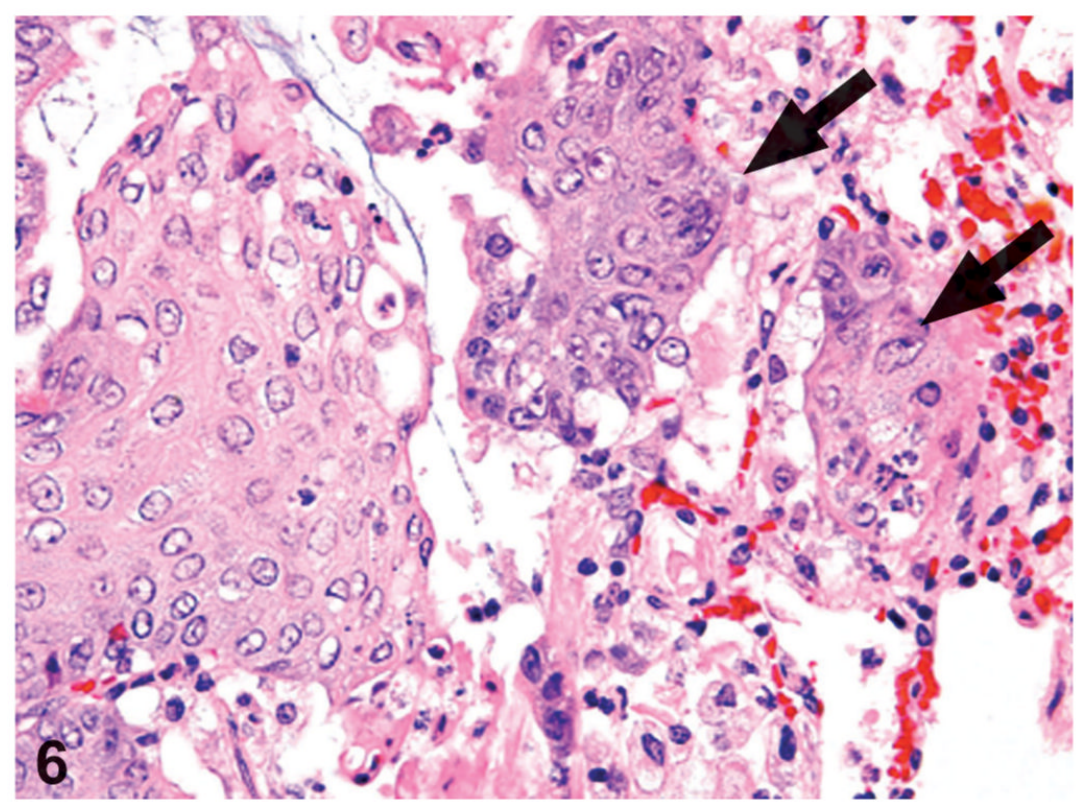

Figure 6.

Squamous cell carcinoma. Invasion of the surrounding lung parenchyma (arrows), increased cellular atypia and pleomorphism can be seen. PCB126 study. H\&E, X60. 
Walker et al.

Page 19

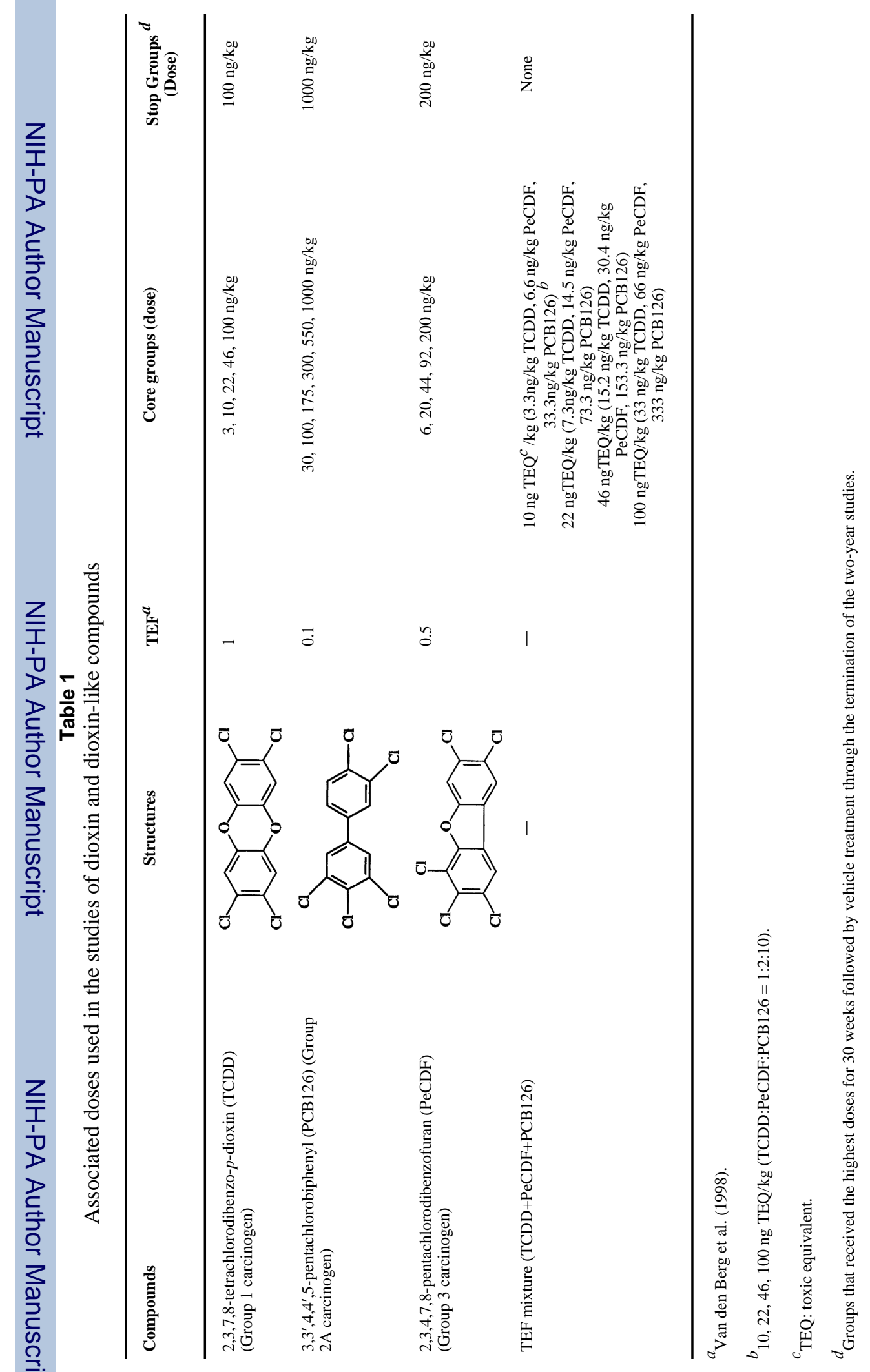




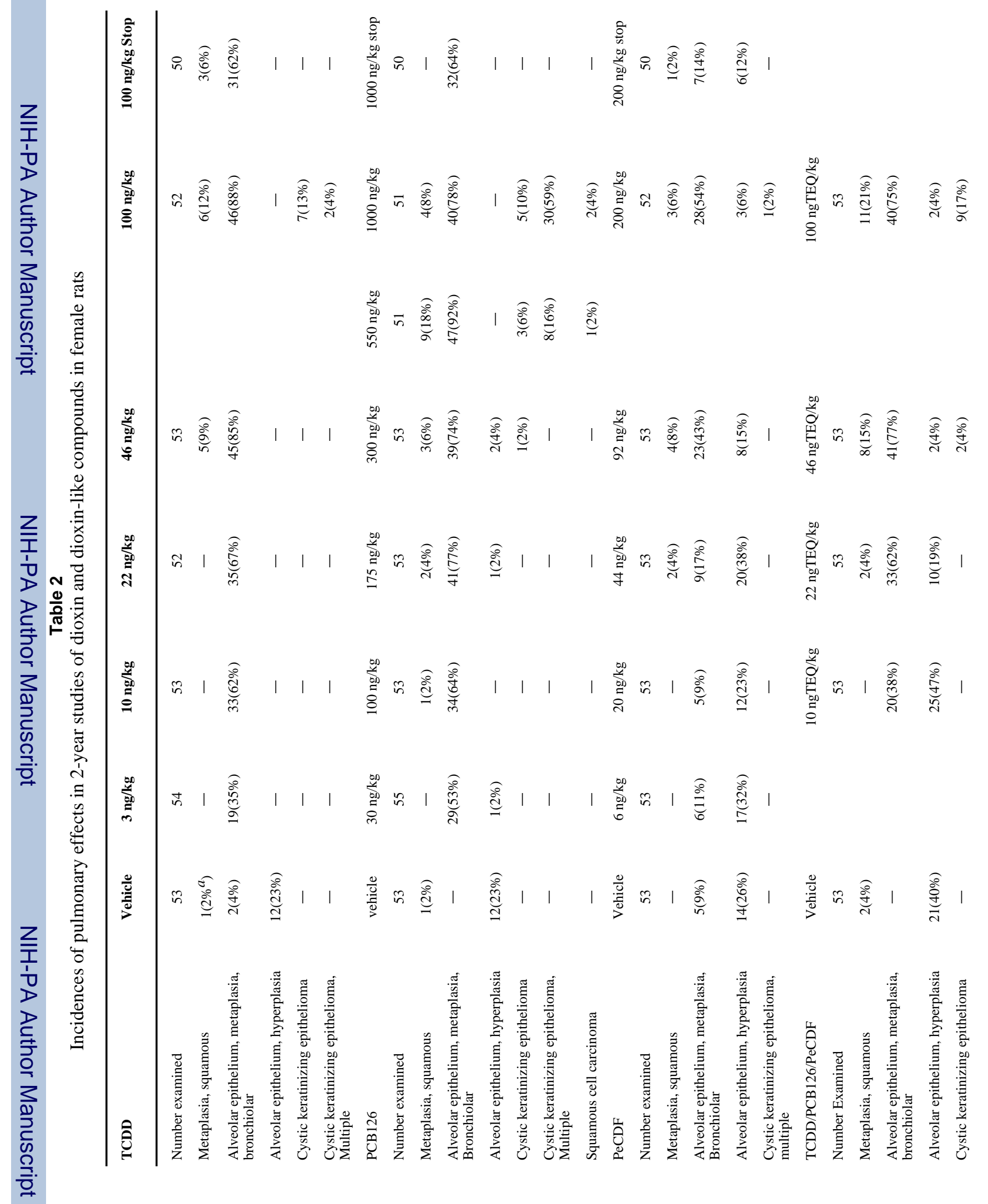




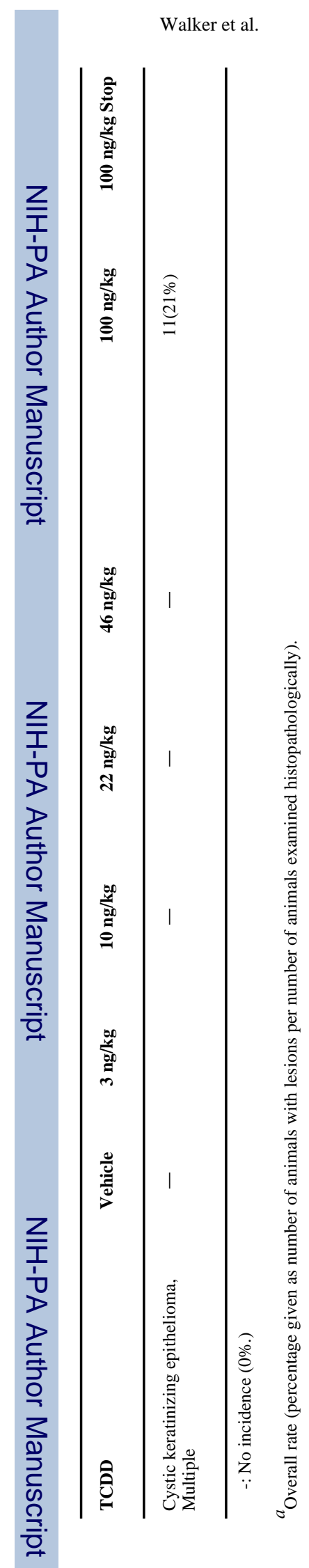

Page 21 
Walker et al.

Page 22

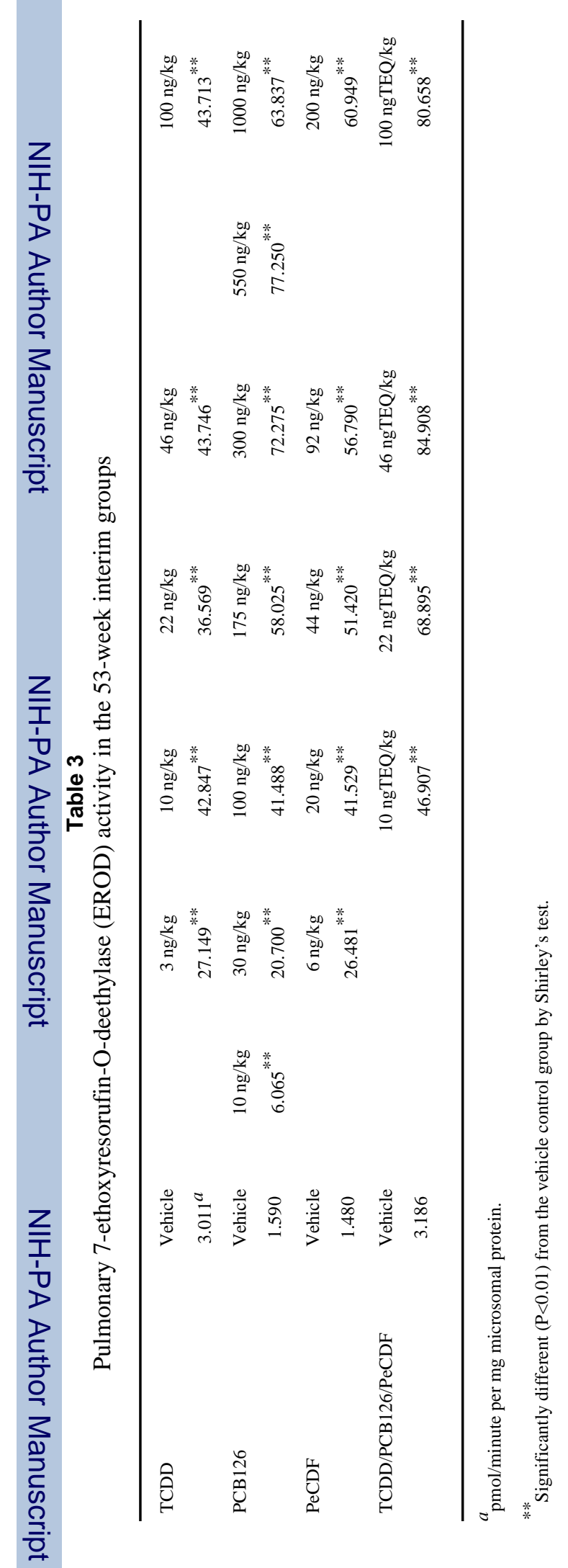

Toxicol Pathol. Author manuscript; available in PMC 2009 January 30. 


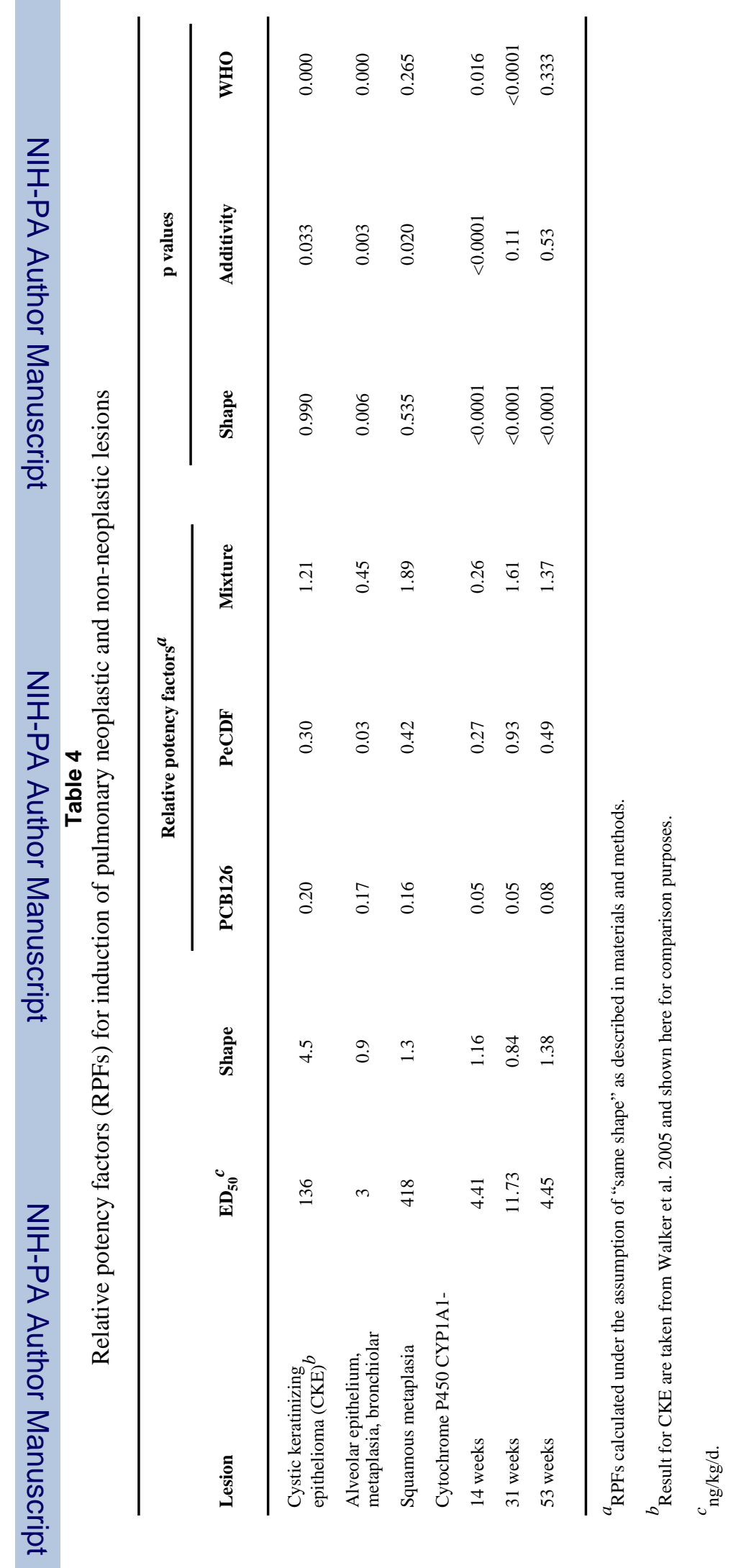

